\title{
INVENTARISASI, DISTRIBUSI, DAN POLA PENYEBARAN Rhododendron EPIFIT DI KEBUN RAYA EKA KARYA BALI
}

\author{
Inventory, distribution, and dispersal pattern of epiphytic Rhododendron \\ at Eka Karya Botanic Gardens Bali
}

\author{
Tri Warseno*, Rajif Iryadi, Dyan Meiningsasi Siswoyo Putri \\ Pusat Penelitian Konservasi Tumbuhan dan Kebun Raya-LIPI \\ Jl. Ir. H Juanda No.13, Bogor, Jawa Barat \\ *Email: triw007@gmail.com
}

Diterima/Received: 23 Desember 2019; Disetujui/Accepted: 29 Maret 2020

\begin{abstract}
Epiphytic Rhododendrons is an important component in an ecosystem, but there is not much information and studies related to its ecology. This research aims to inventory and study the distribution and distribution patterns of Rhododendron populations that grow naturally in Eka Karya Botanic Gardens Bali (KREK). Random sampling method was employed to census the host trees especially old ones (more than 20 years) that overgrown with Rhododendrons. The results showed that there is one species of epiphytic Rhododendron identified in the KREK, namely Rhododendron javanicum. It is found typically in thin substrate thickness with moderate light intensity, mostly in zone III and IV. There were five host species, namely Bischofia javanica Blume, Dacrycarpus imbricatus (Blume) de Laub., Glochidion rubrum Blume, Prunus sp., and Syzygium polyanthum (Wight) Walp. with a total number of 31 trees. The results of this study would provide considerations for KREK managers to conserve, develop and utilize policies of epiphytic Rhododendron species.
\end{abstract}

Keywords: Bali, distribution, epiphytic Rhododendron

\begin{abstract}
Abstrak
Rhododendron epifit merupakan salah satu komponen yang penting dalam ekosistem, tetapi belum banyak informasi dan studi terkait ekologinya. Penelitian ini bertujuan untuk menginventarisasi dan mempelajari distribusi dan pola sebaran populasi Rhododendron yang tumbuh alami di Kebun Raya Eka Karya Bali (KREK). Pohon yang berperan sebagai pohon inang dipilih secara acak terutama pohon yang berumur lebih dari 20 tahun dan sudah ditumbuhi Rhododendron. Berdasarkan hasil inventarisasi dan identifikasi diketahui terdapat satu jenis Rhododendron yang tumbuh epifit di wilayah KREK yaitu Rhododendron javanicum. Jenis ini ditemukan hidup pada ketebalan substrat tipis dengan intensitas cahaya sedang, dan terbanyak pada zona III dan zona IV. Jumlah pohon inang dari $R$. javanicum tercatat sebanyak 31 pohon yang terdiri atas lima jenis, yaitu Bischofia javanica Blume, Dacrycarpus imbricatus (Blume) de Laub., Glochidion rubrum Blume, Prunus sp., and Syzygium polyanthum (Wight) Walp. Hasil dari penelitian ini diharapkan dapat menjadi bahan pertimbangan bagi pengelola Kebun Raya Eka Karya Bali dalam hal kebijakan konservasi, pengembangan, dan pemanfaatan jenis Rhododendron epifit.
\end{abstract}

Kata kunci: Bali, distribusi, Rhododendron epifit 


\section{PENDAHULUAN}

Rhododendron merupakan salah satu marga terbesar dari suku Ericaceae. Tercatat ada lebih dari 1000 jenis Rhododendron tumbuh secara terestrial atau epifit, berbentuk perdu hingga pohon kecil dengan tinggi rata-rata $1,5 \mathrm{~m}$ yang tersebar di seluruh dunia (Sleumer 1966). Menurut Rahman (2008) dan Gibbs et al. (2011), jumlah Rhododendron di Indonesia mencapai 187 jenis. Jenis-jenis tersebut tersebar di Sumatra (27 jenis), Jawa (8 jenis), Kalimantan (9 jenis), Sulawesi (26 jenis), Bali (1 jenis), Nusa Tenggara ( 3 jenis), Maluku (9 jenis), dan Papua Barat (97 jenis).

Tumbuhan epifit, termasuk Rhododendron, merupakan salah satu komponen yang penting dalam ekosistem, tetapi saat ini informasi dan studi terkait ekologinya masih sangat terbatas (Bartels \& Chen 2012). Tumbuhan epifit disebut juga sebagai aerophytes atau tumbuhan udara memiliki akar sejati, hidup menumpang pada tumbuhan atau benda lain untuk mendapatkan dukungan secara mekanik tetapi tidak mengambil nutrisi. Tumbuhan tersebut tidak bersifat parasit. Tumbuhan pendukung tempat epifit tumbuh disebut dengan phorophytes atau tumbuhan inang. Nama epifit berasal dari kata Yunani epi (berarti 'atas') dan phyton (artinya 'tumbuhan') (Benzing 2008). Pentingnya studi tumbuhan epifit untuk penelitian keanekaragaman hayati telah dilaporkan oleh Porembski \& Barthlott (2000). Informasi tentang tingkat spesifisitas inang sangat penting untuk memahami ekologi tumbuhan epifit berpembuluh yang bergantung pada struktur tumbuhan inangnya (Wagner et al. 2015).

Kemampuan penyebaran baik tumbuhan maupun hewan ke lingkungan yang baru adalah faktor penting untuk menentukan tingkat penyebarannya (Clark et al. 1999). Stephenson et al. (2007) melakukan penelitian mengenai pola persebaran biji Rhododendron ponticum, salah satu jenis Rhododendron yang sangat invasif di Kepulauan Inggris, untuk meningkatkan pemahaman ekologi penyebarannya sehingga dapat digunakan dalam menyusun strategi mengontrol distribusinya secara efektif.

Kebun Raya Eka Karya Bali (KREK) memiliki koleksi jenis-jenis Rhododendron yang diperoleh dari kegiatan eksplorasi flora nusantara dan pertukaran biji (seed exchange) maupun Rhododendron epifit yang tumbuh alami menempel pada beberapa jenis pohon, baik pada pohon koleksi maupun non koleksi. Tumbuhan epifit merupakan bagian dari ekosistem yang juga memiliki fungsi ekologi, seperti bagian tanamannya dapat digunakan untuk tempat berlindung beberapa makhluk hidup (satwa) (Sodiq 2009). Penelitian ini bertujuan untuk menginventarisasi dan mempelajari distribusi, serta pola sebaran populasi Rhododendron yang tumbuh alami di KREK. Hasil dari penelitian ini diharapkan dapat menjadi bahan pertimbangan bagi pengelola KREK dalam hal kebijakan konservasi, pengembangan, dan pemanfaatan jenis Rhododendron epifit.

\section{BAHAN DAN METODE}

\section{Lokasi dan waktu}

Penelitian ini dilaksanakan pada November 2017-Januari 2018 di Kebun Raya Eka Karya BaliLIPI, Kabupaten Tabanan Bali. Lokasi penelitian berada pada ketinggian $\pm 1250 \mathrm{~m}$ dpl. Suhu udara pada saat pengukuran $21^{\circ} \mathrm{C}$ dengan kelembapan udara $91 \%$. Rerata curah hujan dalam rentang bulan tersebut adalah $303 \mathrm{~mm} /$ bulan dengan kecepatan angin 0,2-1 km/ jam.

\section{Cara kerja}

Inventarisasi Rhododendron epifit dan tumbuhan inangnya diawali dengan pengeplotan data dengan binokuler terhadap keberadaan Rhododendron epifit dan pengamatan langsung batang pohon inang setinggi dada (diameter breast at height/dbh). Titik posisi inangnya dicatat koordinatnya dengan GPS. Parameter yang diamati mencakup jenis dan jumlah individu Rhododendron epifit yang dijumpai, jenis pohon inang, dan zonasi/ letak Rhododendron epifit pada pohon inang. Titik elevasi Rhododendron epifit didasarkan pada kelas percabangan untuk setiap pohon inang. Pembagian zonasi pada pohon inang mengikuti metode Johansson (1975) (Gambar 1). Identifikasi Rhododendron epifit diawali dengan membuat herbarium Rhododendron epifit, selanjutnya dilakukan pengamatan terhadap ciri-ciri morfologinya dengan mengacu pada Argent (2006). 


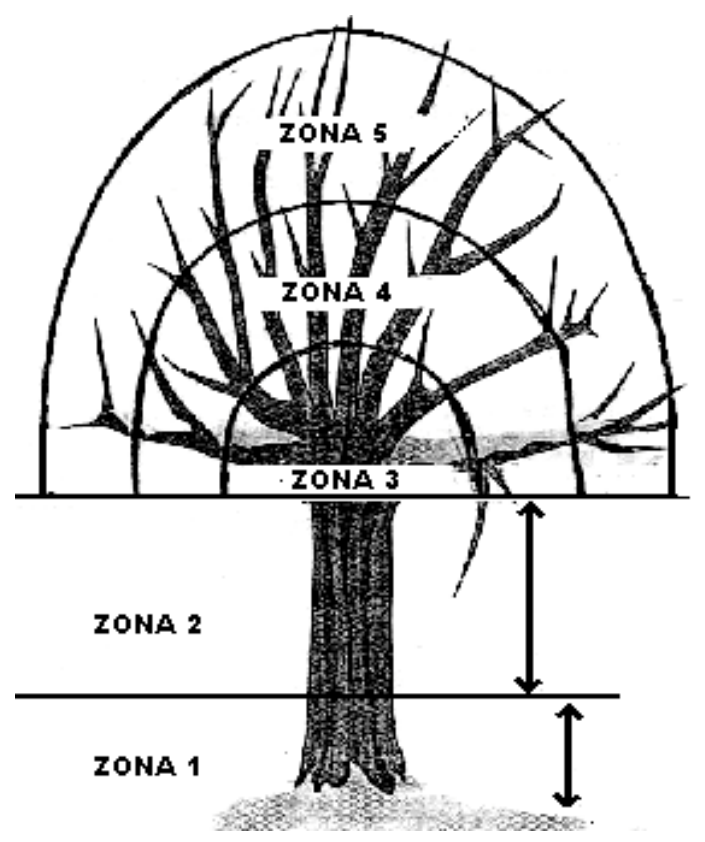

Gambar 1. Zonasi Rhododendron pada pohon inang. zona 1: pangkal pohon (1/3 batang utama); zona 2: batang utama hingga percabangan pertama ( $2 / 3$ batang utama atas); zona 3 : basal percabangan ( $1 / 3$ panjang cabang); zona 4: tengah percabangan ( $1 / 3$ tengah percabangan); zona 5: percabangan terluar ( $1 / 3$ percabangan paling luar) (Johansson 1975)

Data kecepatan angin dan arah angin diperoleh dari Unit Registrasi Koleksi KREK. Data ini digunakan sebagai parameter untuk mengetahui penyebaran jenis yang diamati dan tutupan lahannya. Titik sebaran dilakukan dengan membuat peta plotting lokasi Rhododendron epifit dengan menggunakan open software QGIS 2.01.

\section{Analisis data}

Data hasil pengamatan ditabulasikan dalam microsoft excel yeng berisi jumlah jenis, marga dan suku dari pohon yang menjadi inang Rhododendron epifit, serta zona tempat tumbuh Rhododendron epifit yang dominan. Selanjutnya data ditampilkan dalam bentuk tabel, grafik, dan gambar.

Pada umumnya tumbuhan secara spasial memiliki tiga pola sebaran dasar, yaitu: acak (random), mengelompok (clumped atau aggregated), dan seragam atau merata (uniform) (Ludwig \& Reynolds 1988, Krebs 1989). Pola distribusi Rhododendron epifit diketahui dengan membagi ruang pengamatan menjadi empat kuadran (Gambar 2).

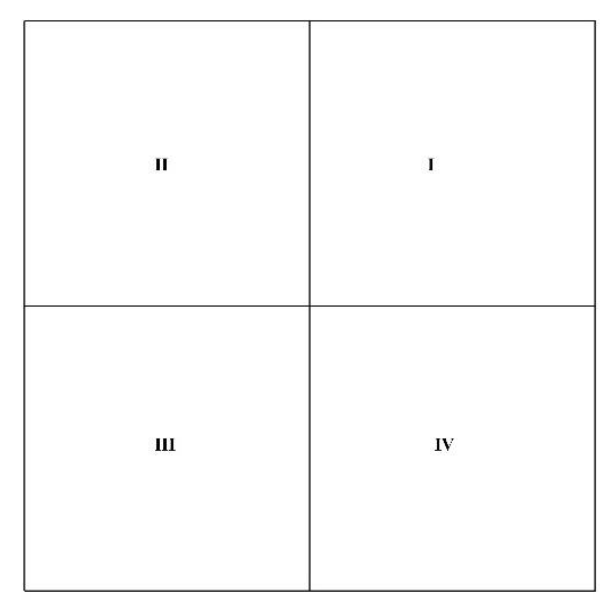

Gambar 2. Plot kuadran pembagian area survei

Pengukuran dalam plot kuadran ini diuji secara statistik dengan metode rasio varian-means (Ludwig \& Reynolds 1988, Krebs 1989). Nilai rasio antara nilai varian dengan nilai rerata sampel disebut dengan indeks dispersi yang dihitung dengan persamaan:

$$
\mathrm{I}=\frac{\sum(\mathrm{X}-\mathrm{Xr})^{2}}{\mathrm{~N}}
$$

Dimana:

I : Nilai indeks dispersi

$X$ : Jumlah individu Rhododendron teramati dalam satu titik pengamatan

$\mathrm{Xr}$ : Jumlah rerata Rhododendron secara keseluruhan

$\mathrm{N}$ : Jumlah total titik pengamatan

Nilai I mengacu pada sebaran Poisson, dimana: $I=1$ pola sebaran acak, $0<1<1$ maka pola sebaran seragam, dan $I>1$ pola sebaran menunjukkan mengelompok. Selanjutnya nilai indeks dispersi diuji dengan Uji chi-square :

$$
x^{2}=I(n-1)
$$

Di mana:

$n$ : jumlah kuadrat yang digunakan;

$x^{2}$ : Nilai chi-square dengan derajat bebas $(n-1)$

Nilai batasan dari nilai chi-square untuk dilakukan uji dua pihak (Gambar 3). Uji indeks dispersi untuk melihat arah penyimpangan, jika hipotesis nol (Ho) diterima (organisme menyebar acak) maka: $x^{2} 0,975<$ chi-square $>x^{2} 0,025$. 


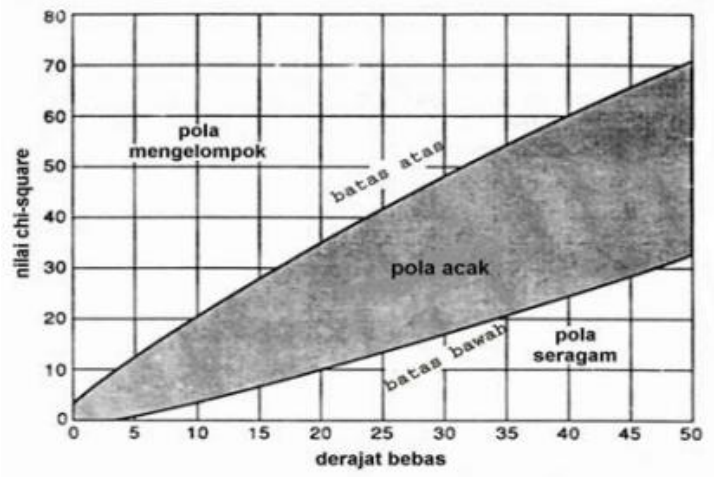

Gambar 3. Nilai kritis uji chi-square untuk nilai dispersi (Krebs 1989)

\section{HASIL DAN PEMBAHASAN}

\section{Jenis dan habitat Rhododendron epifit}

Hasil inventarisasi menemukan satu jenis Rhododendron epifit yang tumbuh pada beberapa jenis pohon inang di KREK, yaitu R. javanicum Benn. Menurut Argent (2006), R. javanicum terdiri atas 6 subspesies, yaitu: $R$. javanicum subsp. brookeanum, $R$. javanicum subsp. cladotrichum, $R$. javanicum subsp. gracile, $R$. javanicum subsp. javanicum, $R$. javanicum subsp. scadenbergii, dan $R$. javanicum subsp. teysmanii. Berdasarkan komunikasi personal dengan Argent (2014), R. javanicum yang tumbuh epifit secara alami di KREK belum pernah dideskripsikan dan dipublikasikan sebelumnya, diduga merupakan subspecies baru sehingga perlu diteliti lebih lanjut mengenai karakter-karakter khusus yang membedakannya dengan subspesies yang sudah ada. Menurut Putri (2011), pada saat berbunga, jenis ini hanya mempunyai tiga sampai empat kuntum bunga dalam satu kali pembungaan dan dalam satu individu. Lama waktu tunas bunga hingga bunga mekar selama 2 minggu dan bunga mekar sempurna bertahan selama 3 minggu. Buah berwarna hijau kemerahan dan apabila telah masak atau matang, buah akan pecah. Lama waktu buah muncul hingga siap menghasilkan biji selama 4-5 minggu.

Tidak semua jenis pohon yang tumbuh di KREK merupakan habitat dari $R$. javanicum (Tabel 1). Ada 5 jenis pohon inang di KREK, yaitu Bischofia javanica Blume, Dacrycarpus imbricatus (Blume) de Laub., Glochidion rubrum Blume, Prunus sp., dan Syzygium polyanthum (Wight) Walp. R. javanicum paling banyak ditemukan tumbuh pada pohon $B$. javanica, yaitu pada zona II, III, IV, dan V. Karakter B. javanica mempunyai permukaan batang yang tidak rata, banyak ditumbuhi lumut maupun paku (Sequiera \& Kumar 2008, Darma et al. 2018). Kondisi inilah yang dapat menjadi akumulasi substrat tumbuhnya $R$. javanicum. Hal tersebut cukup beralasan, karena memudahkan serasah dan berbagai residual dari berbagai hewan yang bersarang pada pohon tersebut menempel dan dalam kurun waktu yang lama akan menumpuk dan menggumpal serta terdekomposisi sehingga menyebabkan batang pohon itu menjadi lembap (Sodiq 2009).

Menurut Tirta \& Sutomo (2014), ditemukan 162 jenis pohon yang menjadi inang anggrek di KREK. Jenis inang anggrek yang paling dominan di KREK adalah $S$. polyanthum dan Eugenia jamboloides dari suku Myrtaceae (Tirta 2004).

Tabel 1. Karakter morfologi pohon inang dan zona tumbuh Rhododendron epifit

\begin{tabular}{|c|c|c|c|c|c|c|c|}
\hline No & Jenis & Suku & $\begin{array}{l}\text { Rata-rata } \\
\text { tinggi } \\
\text { pohon (m) }\end{array}$ & $\begin{array}{l}\text { Jml pohon } \\
\text { yang } \\
\text { diamati }\end{array}$ & $\begin{array}{c}\text { Rata-rata } \\
\text { diameter } \\
\text { pohon }(\mathrm{m})\end{array}$ & $\begin{array}{c}\text { Zona tumbuh } \\
\text { Rhododendron } \\
\text { epifit }\end{array}$ & $\begin{array}{c}\text { Jumlah } \\
\text { Rhododendron } \\
\text { tiap jenis inang }\end{array}$ \\
\hline 1. & $\begin{array}{l}\text { Syzygium } \\
\text { polyanthum } \\
\text { (Wight) Walp. }\end{array}$ & Myrtaceae & 30 & 8 & $\pm 2,01$ & III, IV, V & 27 \\
\hline 2. & $\begin{array}{l}\text { Bischofia javanica } \\
\text { Blume }\end{array}$ & Phyllanthaceae & 29 & 17 & $\pm 1,00$ & II, III, IV, V & 70 \\
\hline 3. & $\begin{array}{l}\text { Dacrycarpus } \\
\text { imbricatus (Blume) } \\
\text { de Laub. }\end{array}$ & Podocarpaceae & 45 & 1 & $\pm 3,50$ & III, IV, V & 13 \\
\hline 4. & $\begin{array}{l}\text { Glochidion rubrum } \\
\text { Blume }\end{array}$ & Phyllanthaceae & 7,5 & 3 & $\pm 1,75$ & III, IV, V & 9 \\
\hline 5. & Prunus sp. & Rosaceae & 8 & 1 & $\pm 2,90$ & III, IV & 5 \\
\hline
\end{tabular}



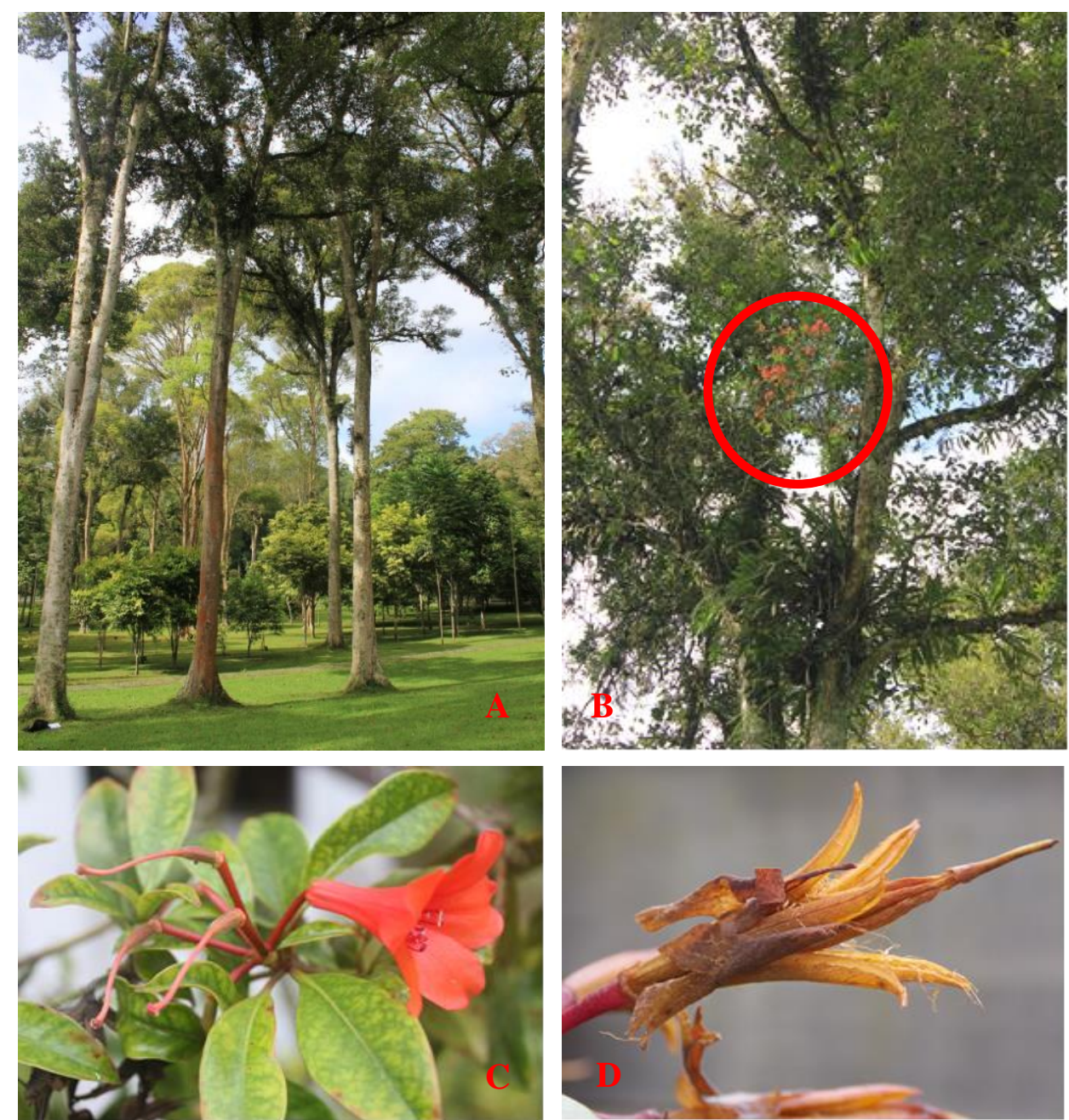

Gambar 4. A. Tumbuhan inang (S. polyanthum); B. Rhododendron javanicum yang tumbuh alami pada pohon S. polyanthum; C. Morfologi daun, bunga dan buah R. javanicum; D. Buah $R$. javanicum yang sudah pecah.

R. javanicum umumnya ditemukan hidup menempel di pohon-pohon dengan batang yang bertekstur tidak rata, kasar, dan seringkali retakretak, seperti pada S. polyanthum. Area kajian didominasi oleh pohon $B$. javanica (17 pohon), $S$. polyanthum (8 pohon), dan G. rubrum (3 pohon), sedangkan jenis $D$. imbricatus dan Prunus sp. hanya ada satu pohon.

Secara umum diameter batang porofit berhubungan erat dengan banyaknya $R$. javanicum yang menempel pada suatu jenis pohon inang. Tanpa membedakan jenis, pohon-pohon inang dengan diameter besar cenderung lebih banyak ditempeli oleh $R$. javanicum, misalnya $D$. imbricatus. Pohon dengan diameter besar, memiliki kondisi kulit pohon yang menguntungkan untuk pertumbuhan epifit termasuk Rhododendron. Kondisi ini disebabkan karena pohon tersebut kulitnya kasar, retak-retak, dan banyak lekukanlekukan, serta lubang-lubang bekas cabang patah, ataupun bekas luka yang membusuk dan dipenuhi oleh humus sehingga mempermudah menempelnya epifit. Namun demikian bukan berarti bahwa setiap pohon yang berdiameter lebih besar meskipun jenisnya sama akan selalu lebih banyak ditempeli epifit.

Menurut Partomihardjo (1991), pohon tempat hidup epifit (inang) seringkali mempunyai penampilan fisik yang khusus seperti mempunyai dahan, cabang, atau ranting yang tumbuhnya relatif mendatar atau miring. Pohon dengan percabangan demikian merupakan habitat yang banyak disukai oleh jenis-jenis epifit seperti Rhododendron. Pohon dengan permukaan kulit batang yang licin dan keras kurang disukai oleh jenis-jenis epifit, sehingga jarang dijumpai epifit yang tumbuh dan hidup 
dengan baik pada pohon seperti itu. Sebaliknya, epifit banyak dijumpai pada pohon-pohon yang mempunyai kulit batang kasar, retak-retak, dan berlekuk sehingga mudah menyimpan air, misalnya pada S. polyanthum serta kondisi tajuk yang relatif baik (tajuk berbentuk payung dengan percabangan yang masih utuh dan tidak terlalu rimbun), meskipun hampir seluruhnya ditemukan memiliki cacat fisik pada batang bebas cabangnya (Murtiningsih et al. 2016).

Dimensi pohon inang yang lebih besar akan menyediakan tempat melekat yang lebih luas, sehingga dapat menampung kelimpahan jenis-jenis epifit yang lebih tinggi. Menurut Bartels \& Chen (2012), karakteristik pohon inang mempengaruhi keanekaragaman dan komposisi tumbuhan epifit. Penyebaran epifit sangat dipengaruhi oleh kondisi substrat (kulit pohon inang) yang mencakup kemiringan dan kekasaran kulit kayu serta penimbunan serasah. Diameter pohon yang umumnya menunjukkan umur tumbuhan, juga merupakan faktor yang berperan dalam menentukan banyaknya individu dan jenis epifit yang menempel pada inang. Pohon yang berdiameter besar memiliki kondisi tajuk dan terlebih kulit pohon yang menguntungkan pertumbuhan anggrek epifit, karena umumnya berkulit kasar, retak-retak, banyak lekukan dan lubang-lubang (Sujalu 2008).

\section{Zonasi $R$. javanicum pada pohon inang}

Berdasarkan hasil pengamatan, $R$. javanicum di KREK pada umumnya menyukai zona III pada pohon inang (daerah yang meliputi bagian basal percabangan atau $1 / 3$ bagian dari total panjang cabang) dan zona IV (tengah percabangan atau $1 / 3$ tengah percabangan). Kondisi ini hampir sama dengan hasil penelitian Lugrayasa \& Mudiana (2000) pada anggrek. Anggrek epifit di KREK banyak dijumpai menempel pada zona III dan zona IV. Keberadaan $R$. javanicum terbanyak pada zona III dan IV berkaitan dengan ketebalan substrat. Kondisi substrat sangat penting dalam keberlangsungan hidup tumbuhan epifit. Substrat berupa moss bersifat spon membantu penyimpanan air dan unsur hara, sehingga kelembapan akar tetap terjaga dan tidak mengalami kekeringan pada saat musim kemarau. Pada penelitian ini diketahui bahwa zona III dan IV memiliki ketebalan substrat yang sedang dan tipis. Pada zona 1 tidak ditemukan Rhododendron epifit dan zona 2 hanya ditemukan sedikit. Hal tersebut disebabkan pada zona tersebut tidak tersedia substrat atau apabila tersedia hanya dalam jumlah yang sangat sedikit. Tirta \& Sutomo (2014) menyebutkan kebanyakan substrat yang menjadi tempat tumbuh anggrek adalah substrat yang tipis. Zonasi pohon inang dan jumlah $R$. javanicum yang ditemukan di masing-masing zona secara lengkap disajikan pada Gambar 5 dan Gambar 6.

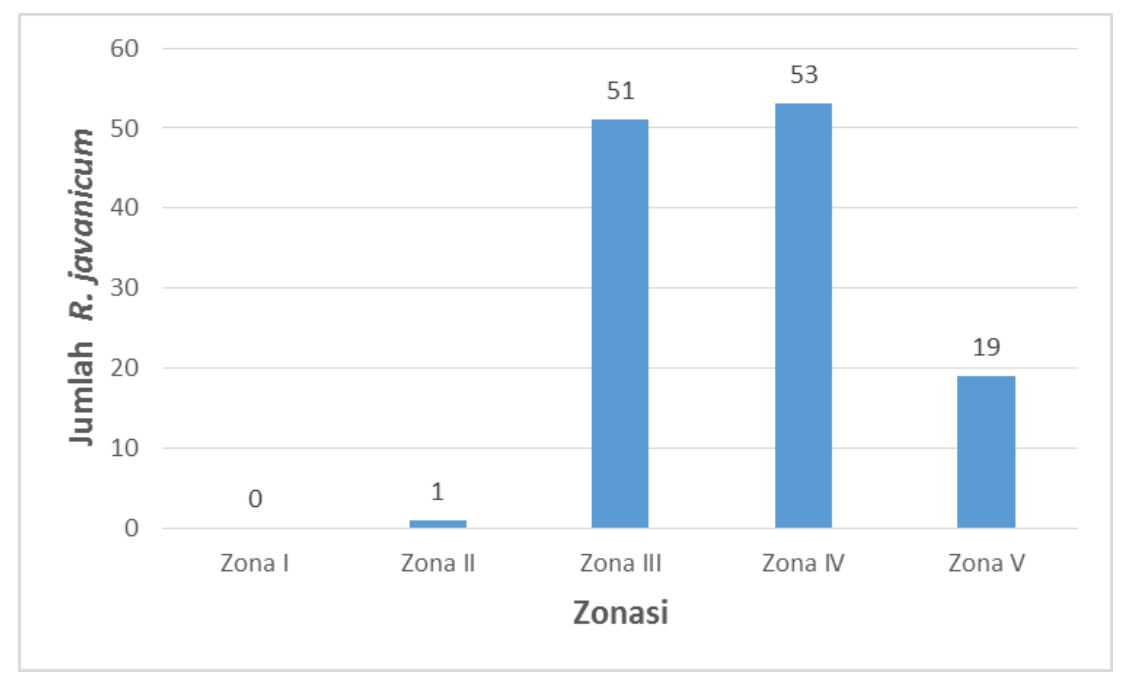

Gambar 5. Zona pohon inang dan jumlah R. javanicum yang ditemukan pada masing-masing zonasi 


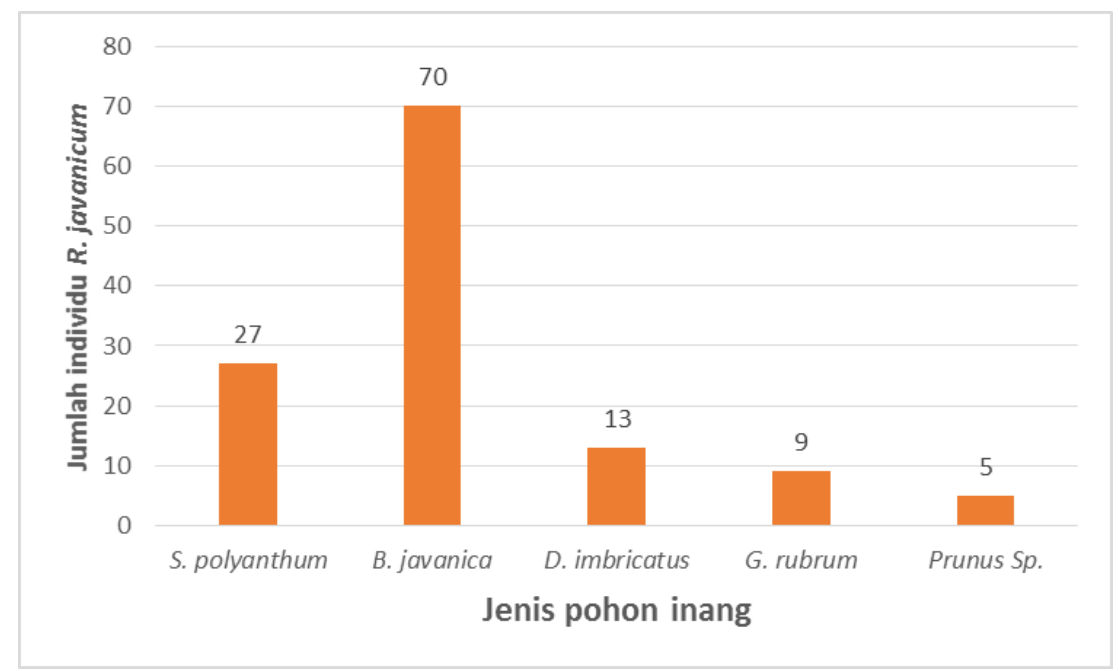

Gambar 6. Jumlah total Rhododendron epifit yang ditemukan pada masing-masing porofit (tumbuhan inang)

Peta distribusi $R$. javanicum yang tumbuh alami di Kebun Raya Eka Karya Bali

Secara umum distribusi $R$. javanicum yang tumbuh alami di KREK dapat dilihat pada Gambar 7. R. javanicum mulai terlihat banyak jumlah individunya (kelas jumlah pohon lebih dari 5-8) terdapat pada pohon inang dengan kode sampel 033, 008, 003, 019, dan 015. Sampel pohon dengan kode 015 merupakan pohon B. javanica dan paling banyak ditumbuhi Rhododendron epifit.
Perhitungan indeks dispersi $(I)$ menunjukkan hasil I = 3,22, yang berarti menunjukan distribusi jenis yang mengelompok $(I>1)$. Uji chi-square dilakukan untuk menguji indeks dispersi dalam melihat arah penyimpangan yang ada (Kurniawan et al. 2008). Hasil uji menunjukkan angka 9,65 dengan jumlah kuadran empat, maka derajat bebas bernilai tiga. Nilai chi-square dan nilai derajat bebas kemudian disesuaikan dengan Gambar 3, sehingga diperoleh hasil yang menunjukkan bahwa pola

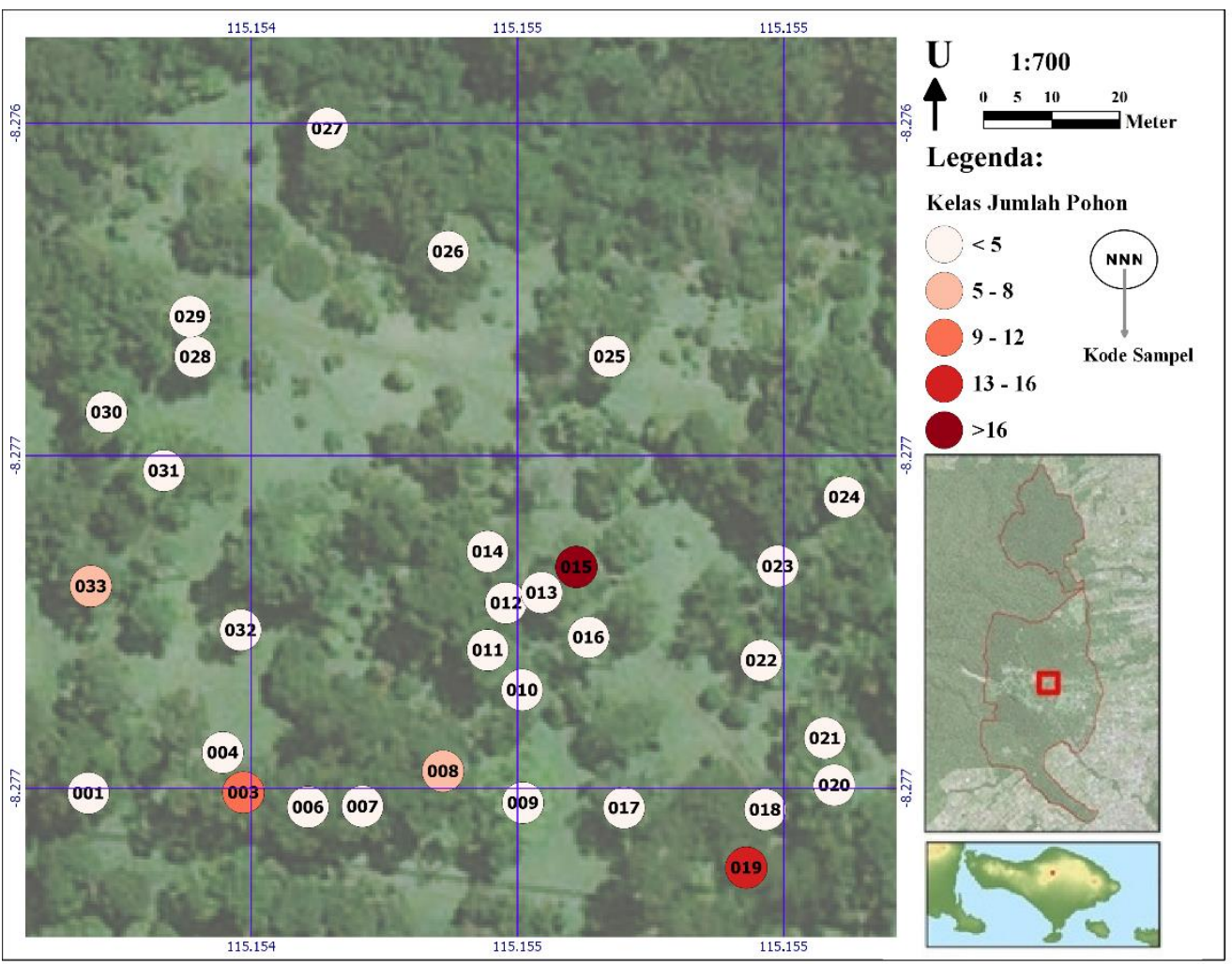

Gambar 7. Peta distribusi R. javanicum yang tumbuh alami di Kebun Raya Eka Karya Bali 
Rhododendron epifit di area penelitian bersifat mengelompok.

Pengelompokan populasi $R$. javanicum yang tumbuh pada pohon inang menunjukkan lokasilokasi yang identik dengan tutupan vegetasi yang tinggi pula. Menurut Hardiansyah (2010), persebaran jenis tumbuhan di alam cenderung mengelompok, dikarenakan cara reproduksi tumbuhan yang umumnya berkembang biak dengan biji, dimana biji atau buah akan jatuh dekat dengan induknya, atau dengan runner (rimpang) yang menghasilkan anakan vegetatif yang masih dekat dengan induknya.

\section{Parameter lingkungan}

Salah satu faktor vektoral yang mampu mempengaruhi pola-pola spasial suatu populasi adalah angin (Hutchinson 1953). Selama pengamatan, angin di wilayah KREK berhembus dominan arah utara dan timur laut dengan kecepatan angin berkisar antara 0,26 km/jam (minggu kedua November 2017) hingga 1,06 $\mathrm{km} / \mathrm{jam}$ (pada bulan Januari 2018) (Gambar 8.). Dengan memperhitungkan peta distribusi jenis $R$. javanicum, pengamatan morfologi pohon inang, dan data arah dan kecepatan angin, dapat diketahui bahwa sumber biji yang paling banyak berasal dari $R$. javanicum yang tumbuh pada tumbuhan $D$. imbricatus (kode sampel 019). Penyebaran biji $R$. javanicum kemudian dibantu oleh angin menyebar ke pohon yang lain ke arah utara dan timur. Hal tersebut dikarenakan $D$. imbricatus merupakan tumbuhan yang tumbuh alami di wilayah KREK dan usianya paling tua, termasuk pohon yang paling tinggi dan berdiameter paling besar diantara tumbuhan inang yang lain.

Stephenson et al. (2007) telah melakukan pengujian model mekanis penyebaran biji $R$. ponticum L., salah satu jenis Rhododendron invasif. Hasil penelitian dengan metode pelepasan terkontrol dan alami menunjukkan bahwa di bentang alam terbuka sebagian besar biji $R$. ponticum tersebar kurang dari $10 \mathrm{~m}$, tetapi dalam proporsi yang sangat kecil $(0,001 \%$ dalam uji coba terkontrol; 0,02\% pelepasan alami) biji tersebar lebih dari $50 \mathrm{~m}$. Pengembangan model penyebaran biji oleh angin secara mekanis semacam ini mempunyai potensi yang besar untuk membantu mengembangkan program kontrol yang efisien untuk tumbuhan asing invasif, tetapi kegiatan lebih lanjut untuk menyelidiki kondisi dimana biji dilepaskan diperlukan penggunaan resolusi spasial dan temporal dari data angin.

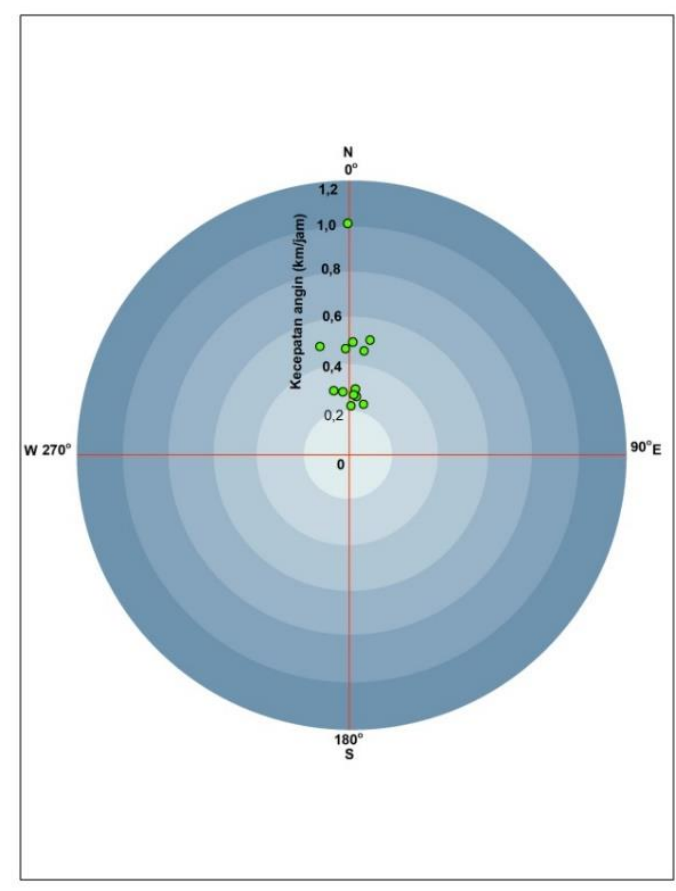

Gambar 8. Grafik arah dan kecepatan angin di Kebun Raya Eka Karya Bali pada saat pengamatan (November 2017-Januari 2018)

Hasil penelitian ini diharapkan dapat menambah referensi mengenai distribusi dan pola penyebaran Rhododendron epifit. Selain itu dapat digunakan sebagai data dasar dalam hal memahami fenomena-fenomena ekologi yang terjadi di alam khususnya di wilayah KREK. Pengelola KREK dapat menjadikan hasil penelitian ini sebagai acuan dan pertimbangan dalam hal pengelolaan dan perawatan pohon koleksi atau pohon reboisasi yang menjadi inang Rhododendron epifit.

\section{KESIMPULAN DAN SARAN}

Inventarisasi Rhododendron epifit di KREK menemukan satu jenis Rhododendron epifit, yaitu R. javanicum. Umumnya, jenis Rhododendron epifit ini ditemukan terbanyak di zona III dan zona IV pohon inangnya. Tumbuhan yang menjadi inang $R$. javanicum yang terdata sebanyak lima jenis pohon, yaitu Bischofia javanica Blume, Dacrycarpus imbricatus (Blume) de Laub., Glochidion rubrum Blume., Prunus sp., dan Syzygium polyanthum (Wight) Walp. Sumber biji $R$. javanicum yang paling banyak yaitu yang tumbuh pada $D$. imbricatus 
(Blume) de Laub. Pola persebaran $R$. javanicum di area penelitian bersifat mengelompok.

Pengelola Kebun Raya Eka Karya Bali hendaknya memperhatikan jenis-jenis pohon yang menjadi inang $R$. javanicum agar tidak terganggu dan memonitor keberadaannya secara rutin agar tidak terancam. Keberadaan $R$. javanicum epifit pada kawasan konservasi khususnya KREK perlu mendapat perhatian supaya dapat termanfaatkan dan terkonservasi dengan baik, serta dapat dijadikan sarana pendidikan lingkungan untuk menjelaskan adanya hubungan Rhododendron epifit dan inangnya.

\section{UCAPAN TERIMA KASIH}

Penulis mengucapkan terima kasih kepada I Made Sudirga dan I Made Suja atas bantuannya dalam pengumpulan data dan identifikasi tumbuhan, serta Unit Registrasi Koleksi BKT Kebun Raya Eka Karya Bali yang telah menyediakan data cuaca pada saat penelitian.

\section{DAFTAR PUSTAKA}

Argent G. 2006. Rhododendron of subgenus Vireya. Royal Botanic Garden Edinburgh. Edinburgh.

Bartels SF, Chen YH. 2012. Mechanisms regulating epiphytic plant diversity. Critical Reviews in Plant Sciences 31: 391-400.

Benzing DH. 2008. Vascular Epiphytes: General Biology and Related Biota. Cambridge University Press. Cambridge.

Clark JS, Silman M, Kern R, Macklin E, HilleRisLambers J. 1999. Seed dispersal near and far: patterns across temperate and tropical forests. Ecology 80: 1475-1494.

Darma IDP, Lestari WS, Priyadi A, Iryadi R. 2018. Paku epifit dan pohon inangnya di Bukit Pengelengan, Tapak dan Lesung, Bedugul, Bali. Jurnal Penelitian Hutan dan Konservasi Alam 15 (1): 41-50.

Gibbs D, Chamberlin D, Argent G. 2011. The Redlist of Rhododendrons. Botanic Gardens Coservation International. Richmond, UK.

Hardiansyah. 2010. Pengantar ekologi tumbuhan. Fakultas Keguruan dan Ilmu Pendidikan UNLAM. Banjarmasin. (Tidak dipublikasikan).
Hutchinson GE. 1953. The concept of pattern ecology. Proceeding of The Academy of Natural Sciences of Philadelphia, 105:1-12.

Johansson DR. 1975. Ecology of epiphytic orchids in West African rain forests. American Orchid Society Bulletin 44: 125-136.

Krebs CJ. 1989. Ecological Methodology. Harper Collins Publisher. Inc. New York.

Kurniawan A, Undaharta NKE dan Pendit IMR. 2008. Asosiasi jenis-jenis pohon dominan di hutan dataran rendah Cagar Alam Tangkoko, Bitung, Sulawesi Utara. Biodiversitas (9): 199-203.

Ludwig JA, Reynolds JF. 1988. Statistical Ecology. John Wiley \& Sons. Inc. Canada.

Lugrayasa IN, Mudiana D. 2000. Anggrek Bulbophyllum di Kebun Raya Bali. BioSMART 2(2):15-20.

Murtiningsih I, Ningsih S, Muslimin. 2016. Karakteristik pohon inang anggrek di kawasan Taman Nasional Lore Lindu (Studi kasus Desa Mataue, Kecamatan Kulawi, Kabupaten Sigi). Warta Rimba 4(2): 32-39.

Partomihardjo T. 1991. Kajian komunitas epifit di hutan Dipterocarpaceae lahan pamah, Wanariset-Kalimantan Timur sebelum kebakaran hutan. Media Konservasi 3(3): 57-66.

Porembski S, Barthlott W. 2000. Biodiversity research in botany. Progress in Botany 21: 335-362.

Putri DMS. 2011. Fenologi Rhododendron spp. (subgenus Vireya) Koleksi Kebun Raya Eka Karya Bali. Jurnal Hortikultura 21 (3): 232244.

Rahman W. 2008. Kurang data, status taksonomi dan hibrid alami dalam konservasi Rhododendron spp. di Indonesia. Buletin Kebun Raya Indonesia 11 (2): 4-14.

Sequiera S, Kumar M. 2008. Epiphyte host relationship of macrolichens in the tropical wet evergreen forests of Silent Valley National Park, Western Ghats, India. Tropical Ecology 49(2): 211-224.

Sleumer H. 1966. Flora Malesiana, Seri 1, Seed plants: Rhododendron 6(4): 474-668.

Sodiq M. 2009. Ketahanan Tanaman terhadap Hama. Universitas Pembangunan Nasional Veteran Press, Surabaya. 
Stephenson CM, Deborah DK, Kirsty JP, Rachel A, Colin E, Justin MT. 2007. Testing mechanistic models of seed dispersal for the invasive Rhododendron ponticum (L.). Perspectives in Plant Ecology, Evolution and Systematics 9: $15-28$.

Sujalu AP. 2008. Analisis vegetasi keanekaragaman jenis anggrek epifit di hutan bekas tebang, Hutan Penelitian Malinau (MRF)-CIFOR. Media Konservasi 13(3): 1-9.

Tirta IG. 2004. Keanekaragaman dan habitat anggrek epifit di Kebun Raya Eka Karya Bali. BioSMART 6 (2): 113-116.

Tirta IG, Sutomo. 2014. Inventarisasi anggrek epifit di Kebun Raya Eka Karya Bali. Widyariset 17 (2): 245-250.

Wagner K, Mendieta-Leiva G, Zotz G. 2015. Host specificity in vascular epiphytes: a review of methodology, empirical evidence and potential mechanisms. AoB Plants 7: 1-25. 